Wojciech Lis*

\title{
DzIAEANia PODEJMOWANE W PRZYPADKACH ZAKAŻEŃ I CHORÓB ZAKAŹNYCH ZE WZGLĘDU NA OCHRONĘ BEZPIECZEŃSTWA OBYWATELI
}

\section{Ochrona życia i zdrowia człowieka jako zadanie państwa}

Człowiek jako istota $\mathrm{z}$ natury wolna samodzielnie dokonuje życiowych wyborów i ponosi ich konsekwencje. Prawo decydowania o sobie wynika z przyrodzonej godności człowieka, którą organy władzy publicznej zobowiązane są szanować i chronić ${ }^{1}$. W związku z tym nikt nie może do niczego zmuszać człowieka, o ile nie wynika to z przepisów prawa, którego zadaniem jest harmonizowanie wolności jednostek w celu zapewnienia optymalnych warunków życia we wspólnocie państwowej. Przyjęte rozwiązanie jest konsekwencją wspólnotowego charakteru natury ludzkiej. Człowiek bowiem nie jest samotną wyspa, ale członkiem różnego rodzaju wspólnot, które współtworzy i których potrzebuje, by móc korzystać z pełni swego człowieczeństwa. Wynika stąd, że człowiek jako istota społeczna może funkcjonować jedynie w grupie społecznej, która stanowi dla niego naturalne środowisko, w którym żyje i realizuje się, ale także wymaga od niego zaangażowania się $\mathrm{w}$ działania podejmowane na rzecz dobra wspólnego, które czasami wymaga ograniczenia części przysługującej mu wolności.

Na straży wolności i praw człowieka stoi państwo, które zapewnia także bezpieczeństwo obywateli w każdej sferze ich życia i w każdych wa-

* Dr hab. Wojciech Lis, Wydział Prawa, Prawa Kanonicznego i Administracji, Katolicki Uniwersytet Lubelski Jana Pawła II.

Zob. art. 30 Konstytucji Rzeczypospolitej Polskiej z dnia 2 kwietnia 1997 r., Dz.U. z 1997 r. Nr 78, poz. 483 z późn. zm. 
runkach. Taki jest cel i sens istnienia państwa. Z uwagi na to, że państwo jest organizacją społeczna, ponieważ organizuje życie poszczególnych jednostek i tworzonych przez nie wspólnot, oczywiste jest, że punktem odniesienia podejmowanych przez nie działań jest, a przynajmniej powinno być dążenie do urzeczywistnienia dobra wszystkich członków wspólnoty państwowej - dobra wspólnego, a tym samym także do realizacji składających się na nie dóbr jednostkowych. Wynika stąd, że działania państwa zawsze odnoszą się do człowieka jako jednostki i jako członka społeczeństwa. Człowiek i tworzone przez niego wspólnoty stanowią więc punkt odniesienia wszelkich działań państwa. Oznacza to, że działania te powinny być ukierunkowane na zapewnienie i ochronę zarówno interesów jednostkowych, jak i interesu zbiorowego. Przy czym działania podejmowane na rzecz ogółu społeczeństwa są zawsze działaniami podejmowanymi na rzecz każdego człowieka, będącego przecież jego integralną częściąa ${ }^{1}$ W związku z tym obowiązek zapewnienia wolności i praw człowieka oraz bezpieczeństwa obywateli nie może być oderwany od treści art. 1 Konstytucji RP, zgodnie z którym „Rzeczpospolita Polska jest dobrem wspólnym wszystkich obywateli". Podejmowanie działań na rzecz urzeczywistnienia tych wartości jest przejawem troski państwa o dobro wspólne, czyli o dobro ogółu swoich obywateli.

W ramach działań podejmowanych przez państwo na rzecz dobra wspólnego należy wskazać te, które są związane z ochroną życia i zdrowia człowieka, czyli wartości o fundamentalnym znaczeniu dla bytu i funkcjonowania każdej wspólnoty. Stanowisko takie potwierdza Konstytucja RP, w myśl której „Rzeczpospolita Polska zapewnia każdemu człowiekowi prawną ochronę życia” (art. 38), „Każdy ma prawo do ochrony zdrowia” (art. 68 ust. 1), a „Władze publiczne są obowiązane do zwalczania chorób epidemicznych i zapobiegania negatywnym dla zdrowia skutkom degradacji środowiska" (art. 68 ust. 4). Przyjęte gwarancje nie dziwią, zważywszy, iż życie ludzkie stanowi wartość o randze najwyższej w naszej cywilizacji i kulturze prawnej. Wartość dobra prawnego, jakim jest życie ludzkie, nie podlega przy tym, na gruncie Konstytucji RP, żadnemu różnicowaniu. $\mathrm{W}$ orzecznictwie konstytucyjnym podkreśla się rangę prawa do prawnej ochrony życia jako podstawowego prawa jednostki, warun-

${ }^{1}$ Zob. W. Lis, Bezpieczeństwo wewnętrzne i porzadek publiczny jako sfera działania administracji publicznej, Lublin 2015, s. 150-151. 
kującego posiadanie i realizację wszelkich innych wolności i praw². Prawo do życia ma charakter przyrodzony, co oznacza, że przysługuje każdemu człowiekowi z natury rzeczy. Państwo nie jest dysponentem życia ludzkiego, niemniej jednak może i powinno zapewniać, poprzez odpowiednie regulacje prawne i działania organów władzy publicznej, jego prawną ochronę. Z konstytucyjnej ochrony życia ludzkiego wywodzi się ochrona zdrowia człowieka. „Ochrona życia ludzkiego nie może być rozumiana wyłącznie jako ochrona minimum funkcji biologicznych niezbędnych do egzystencji, ale jako gwarancje prawidłowego rozwoju a także uzyskania i zachowania normalnej kondycji psychofizycznej, właściwej dla danego wieku rozwojowego (etapu życia). Bez względu na to, jak wiele czynników uzna się za istotne z punktu widzenia owej kondycji, nie ulega wątpliwości, iż obejmuje ona pewien optymalny, z punktu widzenia procesów życiowych, stan organizmu danej osoby, zarówno w aspekcie funkcji fizjologicznych, jak i psychicznych. Stan taki można utożsamić z pojęciem zdrowia psychofizycznego. Konstytucyjne gwarancje ochrony ludzkiego życia muszą więc w sposób konieczny obejmować także ochronę zdrowia" ${ }^{3}$. Wynika stąd, że ochrona zdrowia jest ściśle związana z ochroną życia, a prawo do życia z godnością człowieka. Prawo do ochrony zdrowia to przede wszystkim prawo do zachowania życia i jego obrony w każdej sytuacji, kiedy jest zagrożone ${ }^{4}$. Tym samym prawodawca zobowiązuje władze publiczne do podjęcia działań eliminujących bądź przynajmniej minimalizujących wszelkie zagrożenia dla życia i zdrowia człowieka, które obejmują także zwalczanie chorób epidemicznych. Obowiązek władz publicznych zwalczania chorób epidemicznych dotyczy działań prewencyjnych, profilaktyki, dbałości o higienę, a także kontroli zakażeń i niezwłocznego leczenia wszelkiego rodzaju chorób poprzez odpowiednio zorganizowaną i sprawnie działającą opiekę medyczną ${ }^{5}$. Mając

2 Zob. wyrok Trybunału Konstytucyjnego z dnia 30 września 2008 r., K 44/07, OTK-A 2008, nr 7, poz. 126.

3 Zob. wyrok Trybunału Konstytucyjnego z dnia 28 maja 1997 r., K 26/96, OTK 1997, nr 2, poz. 19.

${ }^{4}$ Zob. wyrok Trybunału Konstytucyjnego z dnia 7 stycznia 2004 r., K 14/03, OTK-A 2004, nr 1, poz. 1. Prawo do ochrony zdrowia obejmuje sytuacje, w których występuje zagrożenie życia i zdrowia; nie obejmuje świadczeń nieleczniczych, nie służących ratowaniu zdrowia, nie mających na celu poprawy czy zachowania zdrowia; wyrok Trybunału Konstytucyjnego z dnia 7 października 2015 r., K 12/14, OTK-A 2015, nr 9, poz. 143.

${ }_{5}$ Zob. B. Banaszak, Komentarz do art. 68, [w:] Konstytucja Rzeczypospolitej Polskiej. Komentarz, Warszawa 2012, s. 412. 
to na uwadze, należy stwierdzić, że władze publiczne, realizując konstytucyjny obowiązek ochrony życia i zdrowia, mogą stosować przymus leczenia w celu wymuszenia zachowań, które z punktu widzenia interesu ogółu (dobra publicznego) są bezwzględnie konieczne. Przyjęte założenie potwierdza art. 31 ust. 3 Konstytucji RP, który dopuszcza możliwość ograniczeń w zakresie korzystania z konstytucyjnych wolności i praw pod warunkiem, że zostały wprowadzone przez ustawę, są konieczne w demokratycznym państwie dla jego bezpieczeństwa lub porządku publicznego bądź dla ochrony środowiska, zdrowia i moralności publicznej albo wolności i praw innych osób, a jednocześnie nie naruszają istoty ograniczanych wolności i praw.

\section{Przymus leczenia}

Podstawę zwalczania chorób epidemicznych stanowi ustawa z dnia 5 grudnia 2008 r. o zapobieganiu oraz zwalczaniu zakażeń i chorób zakaźnych u ludzi ${ }^{6}$. Ustawa wprowadza obowiązek poddawania się badaniom mającym na celu wykrywanie zakażeń i chorób zakaźnych, szczepieniom ochronnym, badaniom sanitarno-epidemiologicznym, zabiegom sanitarnym, kwarantannie i izolacji, który także może zostać wyegzekwowany siłą. Możliwość stosowania przymusu w celu realizacji wynikających z ustawy obowiązków ma charakter wyjątkowy, podyktowana jest koniecznością urzeczywistnienia dobra wspólnego, jakim jest zdrowie publiczne, którego zachowanie przynosi korzyść wszystkim. Zgodnie z definicją legalną zdrowie publiczne to stan zdrowotny całego społeczeństwa lub jego części, określany na podstawie wskaźników epidemiologicznych i demograficznych (art. 2 pkt 35).

Stosowanie przymusu leczenia w przypadkach zakażeń i chorób zakaźnych stanowi wyłom od wynikającej z prawa do decydowania o sobie zasady autonomii decyzyjnej, która zezwala na podjęcie czynności leczniczych wyłącznie za zgodą człowieka-pacjenta bądź jego przedstawiciela ustawowego, opiekuna faktycznego albo sądu opiekuńczego ${ }^{7}$. Tymczasem

${ }^{6}$ Ustawa z dnia 5 grudnia 2008 r. o zapobieganiu oraz zwalczaniu zakażeń i chorób zakaźnych u ludzi, tekst jedn., Dz.U. z 2016 r. poz. 1866 z późn. zm.

${ }^{7}$ Zgodnie z art. 32 ust. 1 ustawy z dnia 5 grudnia 1996 r. o zawodach lekarza i lekarza dentysty, tekst jedn., Dz.U. z 2017 r. poz. 125 z późn. zm. „Lekarz może przeprowadzić 
przymus leczenia zakłada możliwość podjęcia czynności leczniczych bez zgody uprawnionego, a nawet pomimo wyrażonego przez niego sprzeciwu. Prawodawca dopuścił możliwość zastosowania przymusu leczenia ze względu na konieczność ochrony bezpieczeństwa obywateli. Państwo ma bowiem obowiązek chronić obywateli przed każdym niebezpieczeństwem, a więc także przed niebezpieczeństwem związanym z zakażeniem się i zapadnięciem na choroby zakaźne. Jest to chyba jedyna sfera leczenia, w której dobro ogółu jest tak wyraźnie uchwytne i niebudzące żadnych wątpliwości, czego konsekwencją są rygorystyczne regulacje ustawy mające za zadanie je chronić. Tutaj nie ma miejsca na indywidualizm i dezynwolturę, ponieważ odbywałoby się to bezpośrednim kosztem innych ${ }^{8}$.

Nie dokonując kompleksowej analizy problematyki związanej z przymusem leczenia, która przerasta swoim zakresem i bogactwem zagadnień ramy artykułu, przedstawione zostaną jedynie wybrane przepisy wspomnianej ustawy uprawniające do przymusowego przeprowadzania czynności terapeutycznych i nieterapeutycznych ze względu na konieczność ochrony zdrowia publicznego. Przymus leczenia, zakładający przełamanie woli człowieka, jest dopuszczalny tylko wtedy, kiedy wynika z woli prawodawcy wyrażonej w ustawie; stosownie do jej postanowień jest dopuszczalny w przypadkach zakażeń i chorób zakaźnych. Przez zakażenie prawodawca rozumie wniknięcie do organizmu i rozwój w nim biologicznego czynnika chorobotwórczego (art. 2 pkt 32), natomiast przez choroby zakaźne - choroby wywołane przez biologiczne czynniki chorobotwórcze, które ze względu na charakter i sposób szerzenia się stanowią zagrożenie dla zdrowia publicznego (art. 2 ust. 3). Przymus leczenia można jednak zastosować nie do wszystkich zakażeń i chorób zakaźnych, lecz tylko do tych objętych wykazem zakażeń i chorób zakaźnych, stanowiącym załącznik do ustawy, oraz biologicznych czynników chorobotwórczych wywołujących te zakażenia i choroby (art. 3 ust. 1), który obejmuje 60 jednostek chorobowych. Prawodawca, świadomy dynamiki zmian dokonujących się w świecie przyrody i postępu naukowego, dopuścił możliwość rozciągnięcia przepisów ustawy również na innego rodzaju (niewymienione w załączniku) zakażenia i choroby zakaźne w drodze rozporządzenia pod

\footnotetext{
badanie lub udzielić innych świadczeń zdrowotnych, z zastrzeżeniem wyjątków przewidzianych w ustawie, po wyrażeniu zgody przez pacjenta".

${ }_{8}$ Zob. M. Boratyńska, Wolny wybór. Gwarancje i granice prawa pacjenta do samodecydowania, Warszawa 2012, s. 519.
} 
warunkiem, że znany jest wywołujący je biologiczny czynnik chorobotwórczy.

Zgodnie z wolą prawodawcy, świadomego łatwości przemieszczania się we współczesnym świecie, przymus leczenia obejmuje nie tylko obywateli polskich, ale wszystkich przebywających na terytorium Rzeczypospolitej Polskiej. Trudno byłoby zapewnić bezpieczeństwo zdrowotne oraz skutecznie przeciwdziałać lub walczyć z zakażeniami i chorobami zakaźnymi, gdyby jakieś grupy osób były wyłączone z nadzoru sanitarno-epidemiologicznego. Mając to na uwadze, prawodawca zobowiązał wszystkich przebywających na terytorium Rzeczypospolitej Polskiej, na zasadach określonych w ustawie, do: 1) poddawania się: a) zabiegom sanitarnym, b) szczepieniom ochronnym ${ }^{9}$, c) poekspozycyjnemu profilaktycznemu stosowaniu leków, d) badaniom sanitarno-epidemiologicznym, w tym również postępowaniu mającemu na celu pobranie lub dostarczenie materiału do tych badań, e) nadzorowi epidemiologicznemu, f) kwarantannie, g) leczeniu, h) hospitalizacji, i) izolacji; 2) zaniechania wykonywania prac, przy wykonywaniu których istnieje możliwość przeniesienia zakażenia lub choroby zakaźnej na inne osoby - jeżeli są osobami zakażonymi, chorymi na chorobę zakaźną lub nosicielami; 3) stosowania się do nakazów i zakazów organów Państwowej Inspekcji Sanitarnej służących zapobieganiu oraz zwalczaniu zakażeń i chorób zakaźnych; 4) udzielania danych i informacji: a) organom Państwowej Inspekcji Sanitarnej, Wojskowej Inspekcji Sanitarnej, Państwowej Inspekcji Sanitarnej Ministerstwa Spraw Wewnętrznych i Administracji, Inspekcji Weterynaryjnej, Wojskowej Inspekcji Weterynaryjnej, Inspekcji Ochrony Środowiska, specjalistycznym jednostkom wskazanym przez organy Państwowej Inspekcji Sanitarnej właściwym ze względu na rodzaj zakażenia lub choroby zakaźnej oraz ośrodkom referencyjnym i instytutom badawczym - niezbędnych do prowadzenia nadzoru epidemiologicznego nad zakażeniami i chorobami zakaźnymi i zapobiegania oraz zwalczania zakażeń i chorób zakaźnych, b) właściwym państwowym inspektorom sanitarnym - niezbędnych do prowadzenia nadzoru epidemiologicznego nad niepożądanymi odczynami poszczepiennymi, c) organom Państwowej Inspekcji Sanitarnej - nie-

${ }^{9}$ Szczepienia ochronne realizowane są zarówno ze względu na dobro osoby szczepionej, jak i osób trzecich. Chodzi bowiem o zjawisko herd immunity („,odporność stadną”). Powyżej pewnego odsetka osobników odpornych w populacji, zmiennego dla różnych gatunków i dla różnych jednostek chorobowych - czynnik zakaźny nie ma jak się szerzyć, a epidemia wygasa w zarodku, M. Boratyńska, Wolny wybór..., s. 532. 
zbędnych do sprawowania nadzoru nad realizacją wskazanych wyżej obowiązków. W przypadku osoby nieposiadającej pełnej zdolności do czynności prawnych odpowiedzialność za wypełnienie tych obowiązków ponosi osoba, która sprawuje prawną pieczę nad osobą małoletnią lub bezradną albo opiekun faktyczny (art. 5 ust. 1-2).

Obowiązki te państwowy powiatowy inspektor sanitarny lub państwowy graniczny inspektor sanitarny może, w drodze decyzji, nałożyć na osobę zakażoną lub chorą na chorobę zakaźną albo osobę podejrzaną o zakażenie lub chorobę zakaźną bądź osobę, która miała styczność ze źródłem biologicznego czynnika chorobotwórczego (art. 33 ust. 1). Poza tym państwowy powiatowy inspektor sanitarny lub państwowy graniczny inspektor sanitarny $\mathrm{w}$ celu zapobieżenia szerzeniu się zakażeń lub chorób zakaźnych może, w drodze decyzji: 1) wprowadzić zakaz wstępu do pomieszczeń skażonych; 2) nakazać przeprowadzenie dekontaminacji, dezynsekcji lub deratyzacji nieruchomości lub pomieszczeń; 3) nakazać przeprowadzenie dekontaminacji przedmiotów, a jeżeli nie jest to możliwe - ich zniszczenie; 4) wprowadzić zakaz korzystania z wody przeznaczonej do spożycia przez ludzi i na potrzeby gospodarcze pochodzącej z ujęć, co do których istnieje podejrzenie skażenia biologicznymi czynnikami chorobotwórczymi; 5) wprowadzić zakaz spożywania żywności podejrzanej o skażenie, a w razie potrzeby zarządzić jej zbadanie, odkażenie, zniszczenie lub przeznaczenie do innych celów; 6) nakazać sekcję zwłok osoby zmarłej, u której rozpoznano lub podejrzewano zakażenie lub chorobę zakaźną; 7) zakazać wykonywania sekcji zwłok ludzi i zwierząt, gdy sekcja zwłok mogłaby prowadzić do zakażenia osób lub skażenia środowiska, z wyjątkiem przypadku, gdy zachodzi podejrzenie popełnienia przestępstwa (art. 33 ust. 2). Decyzjom tym nadaje się rygor natychmiastowej wykonalności. Oznacza to, że decyzja taka może być wykonana przed upływem terminu do wniesienia odwołania, natomiast $\mathrm{w}$ razie jego wniesienia nie wstrzymuje to jej wykonania. $W$ przypadku konieczności poddania osób zakażonych lub chorych na chorobę zakaźną albo osób podejrzanych o zakażenie lub chorobę zakaźną bądź osób, które miały styczność ze źródłem biologicznego czynnika chorobotwórczego, oraz osób z objawami choroby zakaźnej dotychczas nierozpoznanej w kraju - izolacji lub kwarantannie, na wojewodzie spoczywa obowiązek zapewnienia warunków izolacji lub kwarantanny przez zapewnienie odpowiednich pomieszczeń, wyposażenia oraz skierowanie do pracy osób posiadających odpowiednie kwalifikacje (art. 33 ust. 7). 


\section{Szczepienia ochronne}

Szczególną rolę w zapewnianiu zdrowia publicznego pełnią szczepienia ochronne, których celem jest sztuczne uodpornienie organizmu ludzkiego przeciwko chorobie zakaźnej. Związek pomiędzy ochroną zdrowia publicznego a szczepieniami ochronnymi jest oczywisty - szczepienia ochronne zapobiegają rozprzestrzenianiu się oraz zwalczają zakażenia i choroby zakaźne u ludzi. Szczepienia ochronne służą więc zapewnieniu ochrony zdrowia przede wszystkim osób im poddawanych, ale także pozostałych członków społeczeństwa. Zgodnie z postanowieniami art. 17 poddaniu się obowiązkowym szczepieniom ochronnym przeciwko chorobom zakaźnym obowiązane są osoby lub grupy osób wskazane przez Ministra Zdrowia w rozporządzeniu z dnia 18 sierpnia $2011 \mathrm{r}$. w sprawie obowiązkowych szczepień ochronnych ${ }^{10}$. Wykonanie obowiązkowego szczepienia ochronnego jest poprzedzone lekarskim badaniem kwalifikacyjnym w celu wykluczenia przeciwwskazań do wykonania obowiązkowego szczepienia ochronnego ${ }^{11}$. Oznacza to, że poddanie się obowiązkowemu szczepieniu ochronnemu obejmuje nie tylko obowiązek poddania się samemu aktowi podania szczepionki, ale także wszystkim innym czynnościom związanym $z$ tym aktem, w tym lekarskim badaniom kwalifikacyjnym ${ }^{12}$. Po przeprowadzeniu takich badań lekarz wydaje zaświadczenie ze wskazaniem daty i godziny ich wykonania. Obowiązkowego szczepienia ochronnego nie można wykonać, jeżeli między lekarskim badaniem kwalifikacyjnym przeprowadzonym w celu wykluczenia przeciwwskazań do szczepie-

${ }^{10}$ Rozporządzenie Ministra Zdrowia z dnia 18 sierpnia 2011 r. w sprawie obowiązkowych szczepień ochronnych, tekst jedn., Dz.U. z 2016 r. poz. 849 z późn. zm. Z obowiązku poddawania się obowiązkowym szczepieniom ochronnym zwolnione są osoby przebywające na terytorium Rzeczypospolitej Polskiej przez okres krótszy niż trzy miesiące.

${ }^{11}$ Wykonanie tego obowiązku z mocy prawa zabezpieczone jest przymusem administracyjnym oraz odpowiedzialnością regulowaną przepisami ustawy z dnia 20 maja 1971 r. - Kodeks wykroczeń. Oznacza to, że obowiązek poddania dziecka szczepieniu ochronnemu jest bezpośrednio wykonalny. Jego niedochowanie aktualizuje obowiązek wszczęcia postępowania egzekucyjnego, którego rezultatem będzie poddanie dziecka szczepieniu ochronnemu; wyrok Naczelnego Sądu Administracyjnego z dnia 6 kwietnia 2011 r., II OSK 32/11, LEX nr 852219.

12 Zob. wyrok Naczelnego Sądu Administracyjnego w Warszawie z dnia 6 czerwca 2017 r., II GSK 2399/15, LEX nr 2341038. Lekarskie badanie kwalifikacyjne ma na celu ustalenie, czy stan zdrowia osoby pozwala na jej zaszczepienie, jest więc nierozerwalnie związane z czynnością techniczną polegającą na wprowadzeniu szczepionki do organizmu człowieka; zob. wyrok Wojewódzkiego Sądu Administracyjnego w Bydgoszczy z dnia 4 listopada 2015 r., II SA/Bd 871/15, LEX nr 1948739. 
nia a tym szczepieniem upłynęły 24 godziny od daty i godziny wskazanej w zaświadczeniu o przeprowadzeniu takiego badania. W przypadku kiedy lekarskie badanie kwalifikacyjne daje podstawy do długotrwałego odroczenia obowiązkowego szczepienia ochronnego, lekarz kieruje taką osobę objętą obowiązkiem szczepienia ochronnego do konsultacji specjalistycznej. W konsekwencji wykonanie szczepienia ochronnego może zostać odroczone do czasu ustania przeciwwskazań zdrowotnych, co w skrajnych przypadkach może przerodzić się w stałą praktykę prowadzącą do uchylania się od poddania się szczepieniu ochronnemu.

Obowiązkowe szczepienia ochronne przeprowadzają lekarze lub felczerzy, pielęgniarki, położne i higienistki szkolne, posiadający kwalifikacje do przeprowadzania szczepień ochronnych. Osoby przeprowadzające szczepienia ochronne zobowiązane są do: 1) prowadzenia dokumentacji medycznej dotyczącej obowiązkowych szczepień ochronnych, w tym przechowywania karty uodpornienia oraz dokonywania wpisów potwierdzających wykonanie szczepienia; 2) sporządzenia sprawozdania z przeprowadzonych obowiązkowych szczepień ochronnych oraz sprawozdania ze stanu zaszczepienia osób objętych profilaktyczną opieką zdrowotna, które przekazują państwowemu powiatowemu inspektorowi sanitarnemu.

Lekarz sprawujący profilaktyczną opiekę zdrowotną jest zobowiązany do powiadomienia osoby obowiązanej do poddania się obowiązkowym szczepieniom ochronnym lub osoby sprawującej prawną pieczę nad osobą małoletnią lub bezradną albo opiekuna faktycznego o obowiązku poddania się tym szczepieniom, a także poinformowania o szczepieniach zalecanych. Katalog obowiązkowych szczepień ochronnych i szczepień zalecanych jest opracowywany przez ministra właściwego do spraw zdrowia na podstawie aktualnej sytuacji epidemiologicznej, aktualnej wiedzy medycznej oraz zaleceń Światowej Organizacji Zdrowia. Wywiązując się z tego obowiązku, Minister Zdrowia wydał rozporządzenie z dnia 18 sierpnia 2011 r. w sprawie obowiązkowych szczepień ochronnych oraz rozporządzenie z dnia 16 września 2010 r. w sprawie wykazu zalecanych szczepień ochronnych oraz sposobu finansowania i dokumentowania zalecanych szczepień ochronnych wymaganych międzynarodowymi przepisami zdrowotnymi ${ }^{13}$. Z kolei na ich podstawie Główny Inspektor Sani-

${ }^{13}$ Rozporządzenie Ministra Zdrowia z dnia 16 września 2010 r. w sprawie wykazu zalecanych szczepień ochronnych oraz sposobu finansowania i dokumentowania zalecanych 
tarny ogłasza $\mathrm{w}$ formie komunikatu $\mathrm{w}$ dzienniku urzędowym ministra właściwego do spraw zdrowia Program Szczepień Ochronnych na dany rok, ze szczegółowymi wskazaniami dotyczącymi stosowania poszczególnych szczepionek, w terminie do dnia 31 października roku poprzedzającego realizację tego programu. Należy dodać, że obowiązek poddania się przymusowym szczepieniom ochronnym wynika wprost z przepisu prawa (art. 5 ust. 1 pkt 1 lit. b i art. 17 ust. 1), w związku z tym nie ma potrzeby konkretyzacji tego obowiązku w formie decyzji administracyjnej, przez co obowiązek ten jest bezpośrednio wykonalny ${ }^{14}$. W ustawie został więc przewidziany ogólny obowiązek poddania się szczepieniom ochronnym, natomiast $\mathrm{w}$ rozporządzeniu uszczegółowiono i opisano m.in. osoby lub grupy osób podlegające temu obowiązkowi oraz wykaz chorób zakaźnych objętych obowiązkiem szczepień ochronnych ${ }^{15}$.

Obowiązkowe szczepienia ochronne i poprzedzające ich wykonanie lekarskie badania kwalifikacyjne, a także konsultacje specjalistyczne u ubezpieczonych oraz osób nieposiadających uprawnień z tytułu ubezpieczenia zdrowotnego przeprowadzają świadczeniodawcy, z którymi Narodowy Fundusz Zdrowia zawarł umowy o udzielanie tych świadczeń. Koszty przeprowadzenia obowiązkowych szczepień ochronnych i lekarskich badań kwalifikacyjnych oraz konsultacji specjalistycznych ubezpieczonych są finansowane na zasadach określonych w przepisach o świadczeniach opieki zdrowotnej finansowanych ze środków publicznych, z kolei koszty przeprowadzenia obowiązkowych szczepień ochronnych i lekarskich badań kwalifikacyjnych oraz konsultacji specjalistycznych osób nieposiadających uprawnień z tytułu ubezpieczenia zdrowotnego są finansowane z budżetu państwa z części, której dysponentem jest minister właściwy do spraw zdrowia (art. 18 ust. 1-3).

szczepień ochronnych wymaganych międzynarodowymi przepisami zdrowotnymi, Dz.U. z 2010 r. Nr 180, poz. 1215.

14 Zob. wyrok Wojewódzkiego Sądu Administracyjnego w Bydgoszczy z dnia 4 listopada 2015 r., II SA/Bd 871/15, LEX nr 1948739.

${ }_{15}$ Zob. wyrok Naczelnego Sądu Administracyjnego z dnia 12 czerwca 2014 r., II OSK 1312/13, LEX nr 1519262. 


\section{Badania sanitarno-epidemiologiczne}

Wykrywaniu i zwalczaniu zakażeń i chorób zakaźnych służą obowiązkowe badania sanitarno-epidemiologiczne, którym podlegają: 1) podejrzani o zakażenie lub chorobę zakaźną; 2) noworodki, niemowlęta i kobiety w ciąży, podejrzane o zakażenie lub chorobę zakaźną mogącą się szerzyć z matki na płód lub dziecko; 3) nosiciele, ozdrowieńcy oraz osoby, które były narażone na zakażenie przez styczność z osobami zakażonymi, chorymi lub materiałem zakaźnym; na które kieruje ich właściwy dla ich miejsca pobytu państwowy powiatowy inspektor sanitarny; 4) uczniowie, studenci i doktoranci kształcący się do wykonywania prac, przy wykonywaniu których istnieje możliwość przeniesienia zakażenia lub choroby zakaźnej na inne osoby, na które kieruje ich kierujący szkołą albo rektor uczelni lub osoba przez nich upoważniona; 5) osoby podejmujące lub wykonujące prace, przy wykonywaniu których istnieje możliwość przeniesienia zakażenia lub choroby zakaźnej na inne osoby, na które kieruje ich pracodawca albo zlecający wykonanie prac. Wykonane badania sanitarno-epidemiologiczne oraz ich wyniki są odnotowywane w dokumentacji medycznej pacjenta (art. 6). Badania sanitarno-epidemiologiczne przeprowadzają lekarze podstawowej opieki zdrowotnej lub lekarze wykonujący zadania służby medycyny pracy. Po przeprowadzeniu badania wydają oraz przekazują uczniom, studentom i doktorantom kształcącym się do wykonywania prac, przy wykonywaniu których istnieje możliwość przeniesienia zakażenia lub choroby zakaźnej na inne osoby; osobom podejmującym lub wykonującym prace, przy wykonywaniu których istnieje możliwość przeniesienia zakażenia lub choroby zakaźnej na inne osoby, oraz pracodawcy albo osobie zlecającej wykonanie prac orzeczenie lekarskie: 1) o zdolności do wykonywania prac, przy wykonywaniu których istnieje możliwość przeniesienia zakażenia lub choroby zakaźnej na inne osoby; 2) o czasowych lub trwałych przeciwwskazaniach do wykonywania prac, przy wykonywaniu których istnieje możliwość przeniesienia zakażenia lub choroby zakaźnej na inne osoby (art. 7 ust. 1-2). Osoby, u których orzeczono czasowe lub trwałe przeciwwskazania do wykonywania prac, przy wykonywaniu których istnieje możliwość przeniesienia zakażenia lub choroby zakaźnej na inne osoby, nie mogą wykonywać tych prac. Pracodawca lub zlecający wykonanie prac jest obowiązany, z zachowaniem poufności, niezwłocznie odsunąć pracownika lub wykonującego prace od wykonywania takich prac (art. 10 ust. 1). 


\section{Obowiązkowa izolacja, hospitalizacja i kwarantanna}

Działaniem podejmowanym w przypadkach zakażeń i chorób zakaźnych jest przyjęcie do szpitala zapewniającego skuteczną izolację i obowiązkowa hospitalizacja, której podlegają: 1) osoby chore na gruźlicę $\mathrm{w}$ okresie prątkowania oraz osoby $\mathrm{z}$ uzasadnionym podejrzeniem o prątkowanie; 2) osoby chore i podejrzane o zachorowanie na: a) błonicę, b) cholerę, c) dur brzuszny, d) dury rzekome A, B, C, e) dur wysypkowy (w tym choroba Brill-Zinssera), f) dżumę, g) grypę H7 i H5, h) ostre nagminne porażenie dziecięce (poliomyelitis) oraz inne ostre porażenia wiotkie, w tym zespół Guillaina-Barrégo, i) ospę prawdziwa, j) zespół ostrej niewydolności oddechowej (SARS), k) tularemię, l) waglik, m) wściekliznę, n) zapalenie opon mózgowo-rdzeniowych i mózgu, o) wirusowe gorączki krwotoczne, w tym żółtą gorączkę. W przypadku podejrzenia lub rozpoznania zakażenia lub choroby zakaźnej, o której mowa wyżej, lekarz lub felczer jest obowiązany pouczyć pacjenta o obowiązku hospitalizacji oraz skierować go do szpitala. Fakt udzielenia pouczenia jest potwierdzany wpisem w dokumentacji medycznej oraz podpisem pacjenta. Informacja o skierowaniu do szpitala jest przekazywana państwowemu powiatowemu inspektorowi sanitarnemu właściwemu dla miejsca rozpoznania zakażenia lub choroby zakaźnej. W przypadku samowolnego opuszczenia szpitala przez osobę podlegającą obowiązkowej hospitalizacji przed zakończeniem badań diagnostycznych lub leczenia kierownik szpitala jest obowiązany do niezwłocznego, nie później jednak niż w ciągu 24 godzin od chwili uzyskania informacji o samowolnym opuszczeniu szpitala, powiadomienia o tym fakcie państwowego powiatowego inspektora sanitarnego właściwego dla siedziby szpitala (art. 34 ust. 1-1c).

W celu wyeliminowania zagrożenia rozprzestrzeniania się zakażeń i chorób zakaźnych osoby zdrowe, które pozostawały w styczności z chorymi na szczególnie niebezpieczne jednostki chorobowe: cholerę, dżumę płucna, ospę prawdziwa, wirusowe gorączki krwotoczne oraz zespół ostrej niewydolności oddechowej, podlegają obowiązkowej kwarantannie lub nadzorowi epidemiologicznemu przez okres nie dłuższy niż: 5 dni - w przypadku cholery, 6 dni - w przypadku dżumy płucnej, 21 dni w przypadku ospy prawdziwej, $21 \mathrm{dni}-\mathrm{w}$ przypadku wirusowych gorączek krwotocznych, 10 dni - w przypadku zespołu ostrej niewydolności oddechowej - licząc od ostatniego dnia styczności. 
Lekarz sprawujący opiekę nad osobą poddaną izolacji, hospitalizacji lub kwarantannie na podstawie decyzji o nałożeniu obowiązków, mających na celu zapobieganie oraz zwalczanie zakażeń i chorób zakaźnych u ludzi, o których mowa $\mathrm{w}$ art. 5 ust. 1, ma obowiązek poinformowania tej osoby o przyczynach zastosowania tego środka. Celem obowiązkowej izolacji, hospitalizacji lub kwarantanny jest uniemożliwienie przeniesienia się zakażenia lub choroby zakaźnej na inne osoby. W przypadku niewyrażenia zgody na izolację, hospitalizację lub kwarantannę przez osobę im poddaną kierownik podmiotu leczniczego, w którym umieszczona jest ta osoba, ma obowiązek powiadomienia jej o przysługujących jej środkach odwoławczych. Kierownik podmiotu leczniczego, w którym wykonywana jest decyzja o nałożeniu obowiązków mających na celu zapobieganie oraz zwalczanie zakażeń i chorób zakaźnych u ludzi, o których mowa $\mathrm{w}$ art. 5 ust. 1, jest obowiązany do powiadomienia rodziny lub osoby wskazanej przez osobę poddaną izolacji, hospitalizacji lub kwarantannie o poddaniu takiej osoby izolacji, hospitalizacji lub kwarantannie. Informację o wykonaniu tych czynności wpisuje się do dokumentacji medycznej pacjenta (art. 39 ust. 1-4).

Obowiązkowemu leczeniu podlegają osoby chore na: gruźlicę płuc, kiłę i rzeżączkę. W przypadku podejrzenia lub rozpoznania zakażenia lub choroby zakaźnej tego rodzaju lekarz lub felczer jest obowiązany pouczyć pacjenta o obowiązku leczenia. Fakt udzielenia pouczenia jest potwierdzany wpisem lekarza lub felczera w dokumentacji medycznej oraz podpisem pacjenta. W przypadku uchylania się od obowiązku leczenia lekarz prowadzący leczenie niezwłocznie powiadamia o tym fakcie państwowego powiatowego inspektora sanitarnego właściwego dla miejsca udzielania świadczenia zdrowotnego (art. 40 ust. 1-1c). Osoby, które miały styczność z chorymi na gruźlicę płuc w okresie prątkowania, chorymi na kiłę, rzeżączkę, dur brzuszny, chorymi na inwazyjne zakażenia dwoinką zapalenia opon mózgowo-rdzeniowych (Neisseria meningitidis) lub pałeczką zapalenia opon mózgowo-rdzeniowych (Haemophilus influenzae typ B, podlegają nadzorowi epidemiologicznemu, badaniu klinicznemu, badaniom diagnostycznym, a także, w razie potrzeby, profilaktycznemu stosowaniu leków.

W przypadku podejrzenia lub rozpoznania zachorowania na chorobę szczególnie niebezpieczną i wysoce zakaźną ${ }^{16}$ lekarz przyjmujący do

${ }^{16}$ Choroba szczególnie niebezpieczna i wysoce zakaźna - choroba zakaźna łatwo rozprzestrzeniająca się, o wysokiej śmiertelności, powodująca szczególne zagrożenie dla 
szpitala, miejsca izolacji lub odbywania kwarantanny, kierując się własną oceną stopnia zagrożenia dla zdrowia publicznego, poddaje osobę podejrzaną o zachorowanie, chorą na chorobę szczególnie niebezpieczną i wysoce zakaźną lub osobę narażoną na zakażenie hospitalizacji, izolacji lub kwarantannie oraz badaniom, również w przypadku gdy brak jest decyzji o nałożeniu obowiązków mających na celu zapobieganie oraz zwalczanie zakażeń i chorób zakaźnych u ludzi, o których mowa w art. 5 ust. 1, a osoba podejrzana o zachorowanie, chora lub narażona na zakażenie nie wyraża zgody na hospitalizację, izolację, kwarantannę lub wykonanie badania. O przyjęciu takiej osoby lekarz przyjmujący do szpitala, miejsca izolacji lub odbywania kwarantanny jest obowiązany niezwłocznie zawiadomić państwowego powiatowego inspektora sanitarnego właściwego dla szpitala, miejsca izolacji lub odbywania kwarantanny. Poza tym lekarz przyjmujący do szpitala, miejsca izolacji lub odbywania kwarantanny jest obowiązany poinformować osobę podejrzaną o zachorowanie, chorą lub narażoną na zakażenie i jej osoby najbliższe o przesłankach uzasadniających podjęte działania oraz dokonać odpowiedniego wpisu w dokumentacji medycznej (art. 35 ust. 1-4).

\section{Stosowanie środków przymusu bezpośredniego}

Zgodnie z wolą prawodawcy wobec osoby, która nie poddaje się obowiązkowi szczepienia, badaniom sanitarno-epidemiologicznym, zabiegom sanitarnym, kwarantannie lub izolacji, a u której podejrzewa się lub rozpoznano chorobę szczególnie niebezpieczną i wysoce zakaźna, stanowiącą bezpośrednie zagrożenie dla zdrowia lub życia innych osób, może być zastosowany środek przymusu bezpośredniego polegający na przytrzymywaniu, unieruchomieniu lub przymusowym podaniu leków. Środek przymusu bezpośredniego może być zastosowany tylko w przypadku kumulatywnego zaistnienia tych przesłanek. Wynika stąd, że środków przymusu bezpośredniego nie można stosować wobec osób, które nie poddają się obowiązkowi hospitalizacji czy leczenia. O zastosowaniu środka przymusu bezpośredniego decyduje lekarz lub felczer, który

zdrowia publicznego i wymagająca specjalnych metod zwalczania, w tym cholera, dżuma, ospa prawdziwa, wirusowe gorączki krwotoczne (art. 2 pkt 4). 
określa jego rodzaj oraz osobiście nadzoruje jego wykonanie przez osoby wykonujące zawody medyczne. Należy podkreślić, że zastosowanie środka przymusu bezpośredniego nie wymaga uprzedniej decyzji państwowego powiatowego inspektora sanitarnego. Uproszczenie postępowania wynika z konieczności doraźnej potrzeby podjęcia szybkiej interwencji. Rozwiązanie to wskazuje dobitnie na prymat interesu publicznego nad prawem jednostki do samostanowienia ${ }^{17}$. Każdy przypadek zastosowania środka przymusu bezpośredniego odnotowuje się w dokumentacji medycznej. Lekarz lub felczer może zwrócić się do Policji, Straży Granicznej lub Żandarmerii Wojskowej o pomoc w zastosowaniu środka przymusu bezpośredniego. Udzielenie pomocy następuje pod warunkiem wyposażenia funkcjonariuszy lub żołnierzy w środki chroniące przed chorobami zakaźnymi przez tego lekarza lub felczera. Przed zastosowaniem środka przymusu bezpośredniego uprzedza się o tym osobę, wobec której środek przymusu bezpośredniego ma być zastosowany, i fakt ten odnotowuje się w dokumentacji medycznej. Uprzednie poinformowanie o możliwości zastosowania środka przymusu bezpośredniego ma służyć zmotywowaniu osoby, wobec której ma on być zastosowany, do poddania się obowiązkowi szczepienia, badaniom sanitarno-epidemiologicznym, zabiegom sanitarnym, kwarantannie lub izolacji dobrowolnie.

Zgodnie z zasadą minimalizacji negatywnych skutków zastosowania środka przymusu bezpośredniego należy wybrać środek możliwie najmniej uciążliwy dla osoby, wobec której ma być zastosowany, natomiast przy jego stosowaniu należy zachować szczególną ostrożność i dbałość o dobro osoby, wobec której jest on stosowany. Przymus bezpośredni polegający na unieruchomieniu może być stosowany nie dłużej niż 4 godziny. W razie potrzeby stosowanie tego rodzaju środka przymusu bezpośredniego może być przedłużone na następne okresy 6-godzinne, przy czym nie dłużej niż 24 godziny łącznie. Przytrzymywanie jest doraźnym, krótkotrwałym unieruchomieniem osoby z użyciem siły fizycznej. Unieruchomienie jest dłużej trwającym obezwładnieniem osoby z użyciem pasów, uchwytów, prześcieradeł lub kaftana bezpieczeństwa. Przymusowe podanie leku jest doraźnym lub przewidzianym w planie postępowania leczniczego wprowadzeniem leków do organizmu osoby bez jej zgody (art. 36). Z ustawy nie wynika expressis verbis, o jakiego rodzaju leki chodzi, ale praktycznie może chodzić tylko o sedację ze względu na

\footnotetext{
${ }_{17}$ Zob. R. Kubiak, Prawo medyczne, Warszawa 2014, s. 356.
} 
konieczność spacyfikowania osoby, która się nie poddaje ${ }^{18}$. Uprawnienie do zastosowania środków przymusu bezpośredniego powinno być wykorzystywane w sposób bardzo rozważny z poszanowaniem godności człowieka, przeciwko któremu zostały zastosowane. Przy czym środki przymusu bezpośredniego są tylko narzędziem służącym do realizacji celu związanego z czynnościami medycznymi podejmowanymi dla ochrony zdrowia publicznego. Przepisy dotyczące zastosowania środków przymusu bezpośredniego wydają się być bardzo lakoniczne. Prawodawca reguluje wyłącznie czas ich stosowania, pomijając obowiązki związane z kontrolowaniem stanu pacjenta, badaniem pacjenta przed podjęciem decyzji o przedłużeniu ich stosowania czy sprawowania nadzoru nad decyzją o przedłużeniu ich stosowania, chociażby przez innego lekarza.

\section{Przymusowe leczenie w czasie stanu klęski żywiołowej}

Postanowienia dotyczące przymusowego leczenia znajdują się również w ustawie z dnia 18 kwietnia 2002 r. o stanie klęski żywiołowej w postaci katastrofy naturalnej lub awarii technicznej, których skutki zagrażają życiu lub zdrowiu dużej liczby osób, mieniu w wielkich rozmiarach albo środowisku na znacznych obszarach, a pomoc i ochrona mogą być skutecznie podjęte tylko przy zastosowaniu nadzwyczajnych środków, we współdziałaniu różnych organów i instytucji oraz specjalistycznych służb i formacji działających pod jednolitym kierownictwem ${ }^{19}$. W stanie klęski żywiołowej prawodawca dopuszcza możliwość ograniczania wolności i praw człowieka i obywatela, które mogą polegać m.in. na: obowiązku poddania się badaniom lekarskim, leczeniu, szczepieniom ochronnym oraz stosowaniu innych środków profilaktycznych i zabiegów, niezbędnych do zwalczania chorób zakaźnych oraz skutków skażeń chemicznych i promieniotwórczych, a także na obowiązku poddania się kwarantannie (art. 21 ust. 1 pkt 5-6). Podmiotami uprawnionymi do wprowadzania ograniczeń wolności i praw człowieka i obywatela, w granicach dopuszczonych w rozporządzeniu Rady Ministrów o wprowadzeniu stanu klęski żywiołowej, są: 1) wójt (burmistrz, prezydent miasta) albo pełnomocnik

${ }^{18}$ Zob. M. Boratyńska, Wolny wybór..., s. 528.

19 Zob. art. 3 ust. 1 pkt 1 ustawy z dnia 18 kwietnia 2002 r. o stanie klęski żywiołowej, tekst jedn., Dz.U. z 2014 r. poz. 333 z późn. zm. 
do kierowania działaniami prowadzonymi w celu zapobieżenia skutkom klęski żywiołowej lub ich usunięcia - w drodze zarządzenia albo decyzji; 2) starosta albo pełnomocnik do kierowania działaniami prowadzonymi w celu zapobieżenia skutkom klęski żywiołowej lub ich usunięcia - w drodze zarządzenia albo decyzji; 3) wojewoda albo pełnomocnik do kierowania działaniami prowadzonymi w celu zapobieżenia skutkom klęski żywiołowej lub ich usunięcia - w drodze rozporządzenia albo decyzji. Rozporządzenia wojewody lub jego pełnomocnika i zarządzenia wójta (burmistrza, prezydenta miasta) oraz starosty i pełnomocników do kierowania działaniami prowadzonymi w celu zapobieżenia skutkom klęski żywiołowej lub ich usunięcia podlegają ogłoszeniu przez rozplakatowanie obwieszczeń w miejscach publicznych lub w inny sposób miejscowo przyjęty, a także przez ogłoszenie w lokalnej prasie (art. 23 ust. 1-2).

Osoby, które w czasie stanu klęski żywiołowej wbrew obowiązkowi nie poddają się badaniom lekarskim, leczeniu, szczepieniom ochronnym oraz stosowaniu innych środków profilaktycznych i zabiegów niezbędnych do zwalczania chorób zakaźnych oraz skutków skażeń chemicznych i promieniotwórczych, a także nie poddają się obowiązkowi kwarantanny - podlegają karze aresztu albo grzywny (art. 27 ust. 1).

\section{Uwagi końcowe}

Działania podejmowane w przypadkach zakażeń i chorób zakaźnych podyktowane są troską o dobro wspólne, którego istotnym składnikiem jest bezpieczeństwo zdrowotne całej populacji. Ochrona przed zakażeniami i chorobami zakaźnymi gwarantuje przetrwanie i życie w godnych człowieka warunkach. Są to wartości o fundamentalnym znaczeniu dla bytu każdego człowieka i prawidłowego funkcjonowania państwa. W związku z tym nie dziwi możliwość podejmowania różnego rodzaju działań, które mają doprowadzić do poddania się określonym procedurom leczniczym. Działania takie są nie tylko pożądane, ale wręcz konieczne zarówno ze względu na interes indywidualny, jak i zbiorowy, od tego bowiem zależy jakość ludzkiego życia. Należy jednak zauważyć, że w większości przypadków prawodawca ograniczył się wyłącznie do informowania osoby, u której podejrzewa się lub rozpoznano zakażenie lub chorobę zakaźną, o związanych z tym obowiązkach. Wdrożenie pro- 
cedury egzekucyjnej zmierzającej do zastosowania środków przymusu bezpośredniego $\mathrm{w}$ większości przypadków nie przyniesie spodziewanego rezultatu, zwłaszcza wtedy, kiedy chodzi o czynności o charakterze ściśle medycznym, a więc wymagające zaangażowania osoby, u której podejrzewa się lub rozpoznano zakażenie lub chorobę zakaźną. Nie trudno również zauważyć, że działania te w zasadzie nie obejmują osób, które przebywają na terytorium Rzeczypospolitej Polskiej i które praktycznie znajdują się poza jakimkolwiek nadzorem sanitarno-epidemiologicznym. Nikt nie kontroluje ich pod kątem nosicielstwa zakażeń lub chorób zakaźnych, co jest szczególnie niepokojące z uwagi na to, że niektóre z nich mogą być źródłem zakażeń lub chorób zakaźnych wcześniej nie występujących na tym obszarze. To ogromne wyzwanie dla władz publicznych w kontekście masowej migracji i swobodnego przemieszczenia się ludzi.

Słowa kluczowe: bezpieczeństwo zdrowotne, przymus leczenia, zakażenia i choroby zakaźne, szczepienia obowiązkowe, środki przymusu bezpośredniego.

\section{Bibliografia}

\section{Orzecznictwo}

Wyrok Trybunału Konstytucyjnego z dnia 28 maja 1997 r., K 26/96, OTK 1997, nr 2, poz. 19.

Wyrok Trybunału Konstytucyjnego z dnia 7 stycznia 2004 r., K 14/03, OTK-A 2004, nr 1, poz. 1.

Wyrok Trybunału Konstytucyjnego z dnia 30 września 2008 r., K 44/07, OTK-A 2008, nr 7, poz. 126.

Wyrok Trybunału Konstytucyjnego z dnia 7 października 2015 r., K 12/14, OTK-A 2015, nr 9, poz. 143.

Wyrok Naczelnego Sądu Administracyjnego z dnia 6 kwietnia 2011 r., II OSK 32/11, LEX nr 852219.

Wyrok Naczelnego Sądu Administracyjnego z dnia 12 czerwca 2014 r., II OSK 1312/13, LEX nr 1519262.

Wyrok Wojewódzkiego Sądu Administracyjnego w Bydgoszczy z dnia 4 listopada 2015 r., II SA/Bd 871/15, LEX nr 1948739.

Wyrok Naczelnego Sądu Administracyjnego w Warszawie z dnia 6 czerwca 2017 r., II GSK 2399/15, LEX nr 2341038. 


\section{Literatura przedmiotu}

Banaszak B., Komentarz do art. 68, [w:] Konstytucja Rzeczypospolitej Polskiej. Komentarz, Warszawa 2012.

Boratyńska M., Wolny wybór. Gwarancje i granice prawa pacjenta do samodecydowania, Warszawa 2012.

Kubiak R., Prawo medyczne, Warszawa 2014.

Lis W., Bezpieczeństwo wewnętrzne i porządek publiczny jako sfera działania administracji publicznej, Lublin 2015.

\section{ACTIONS TAKEN IN CASES OF INFECTIONS AND DISEASES TO PROTECT THE SAFETY OF CITIZENS}

\section{$S \mathbf{u ~ m ~ m ~ a ~ r ~ y ~}$}

The security of citizens has different faces, so its provision and protection requires the use of many, sometimes controversial, methods and means. One of its kinds is health security pertaining to the entire population of the state. In order to provide them and protect them the state organs can use the coercion of treatment. Its use means that therapeutic activities must be implemented independently and often even against the will of the person being subjected to them. In this way there is a very deep interference in freedom and human rights, including the right to self-determination in terms of treatment and choice of treatment method. These actions are justified by the purpose they serve, namely ensuring control of infections and infectious diseases, that may have unpredictable consequences and consequently to prevent their spread.

Key words: health security, coercion of treatment, infections and infectious diseases, compulsory vaccinations, means of direct coercion.

\section{ДЕЙСТВИЯ СОВЕРШЕНЫ В СЯУЧАЯХ ИНФЕКЦИИ И ИНФЕКЦИОННЫХ БОЛЕЗНЕЙ, УЧИТЫВАЯ ОХРАНУ БЕЗОПАСНОСТИ ГРАЖДАН}

\section{P е 3 г м е}

Безопасность граждан имеет разные стороны, потому его обеспечение и защита требует применения многих, иногда противоречивых, методов и средств. Одним из его видов является безопасность для здоровья, что касается целой популяции жителей государства. Чтобы его обеспечить и защитить органы государства могут применить принудительное лечение. Его применение значит, что будут осуществленные лечебные действия независимо, а даже часто против води человека, к которому будут применены. Таким образом, происходит очень глубокое вмешатель- 
ство к свободе и праве человека, в том числе право к самоопределению в объёме применения к лечению и выбора его способа. Такие действия оправданы целью, которой служат, именно обеспечению контроля над инфекциями и инфекционными болезнями, которые могут иметь тяжелые к предвидению последствия и не позволяя им дальнейшего распространения.

Ключевые слова: безопасность для здоровья, принудительное лечение, инфекция и инфекционные болезни, обязательная вакцинация, средства непосредственного принуждения 